\title{
The effects of indigenous prescribed fire on riparian vegetation in central California
}

\author{
Don L Hankins
}

\begin{abstract}
Introduction: Fire has a long history, but little documented role, as a process in riparian ecosystems. For millennia California Indians have applied fire to riparian ecosystems for a variety of purposes, but the effects of such fires on riparian vegetation are poorly known outside of traditional knowledge structures of indigenous communities.

Methods: This study involved the seasonal application of fire based on traditional ecological knowledge versus alternate burn methods to assess fire effects on riparian vegetation in central California.

Results: While the annual variation amongst treatments was not significant, the results of this study suggest that fall burns support higher overall richness and native species richness; spring burns yield a decrease in overall richness, but an increase in native species richness; and summer burns contribute to an initial decline in overall and native species richness. The evenness indices of treatments increase most with spring and summer burning.

Conclusion: These findings are key to understanding the seasonal role of fire in managing native species in areas prone to non-native or other invasive species. This research demonstrates the application of traditional ecological knowledge to facilitate an understanding of how prescribed fire could aid in the management and conservation of riparian ecosystems.
\end{abstract}

Keywords: Riparian; California Indian; Fire; Indigenous; Traditional ecological knowledge

\section{Introduction}

Fire and riparian areas

Riparian areas are of conservation concern given the services they provide humanity including habitat and cultural resources such as food, medicine, and fiber. Globally riparian areas have been greatly reduced, and in some regions such as California's Central Valley approximately 99\% have been lost due to land use changes (Faber and Holland 1996). Fire is a natural process that maintains heterogeneity in composition and structure of riparian ecosystems (Pilliod et al. 2003). However, relatively few studies have examined the role of fire in riparian ecosystems (Ellis 2001; Bisson et al. 2003; Dwire and Kauffman 2003; Haflofsky and Hibbs 2009; Petit and Naiman 2007), and much of the literature focuses on the effects of high-intensity and high-severity fires on riparian vegetation (e.g., Busch 1995; Gom and Rood 1999; Ellis 2001), or examines larger wildfire impacts on riparian

Correspondence: dhankins@csuchico.edu

Department of Geography and Planning, California State University-Chico, Chico, CA, USA vegetation within a matrix of other vegetation communities (e.g., Everett et al. 2003; Russell and McBride 2001; Kozbiar and McBride 2006; Bendix and Cowell 2010).

Given the rarity of Central Valley riparian ecosystems, prescribed fire can serve as an important safeguard against the temporal devastation of habitat by wildfire. Agee (1999) and Besctha et al. (2004) suggest that fire can serve as a "coarse filter" conservation tool. Furthermore, Agee (1999) notes that fragmenting fuels can prevent the spread of fire along riparian corridors between large habitat patches. It is known that many common plant taxa such as willow (Salix spp.), aspen (Populus tremuloides), and cottonwood (Populus spp.) generally respond to low- to moderate-intensity fire by sprouting (Gom and Rood 1999; Ellis 2001; Arno and AllisonBunnell 2002; Fulé et al. 2004), but their thin bark makes their aboveground stems and trunks particularly vulnerable to high-intensity fire. Quinlan et al. (2003) found that willows were negatively affected by repeated spring burning. Wills (2006) provides an overview of fire in California's Central Valley bioregion-a region less prone

\section{Springer}


to lightning ignitions (see van Wagtendonk and Cayan 2008), but most prone to anthropogenic ignitions given its high pre-contact population density (see Lewis 1973).

\section{Ethnohistoric context}

For millennia California Indians have successfully stewarded the landscape with various methods including fire (Anderson 1993, 2005), with fire being the most influential tool at a landscape scale. Biswell (1989) suggests that such burning has been instrumental in shaping California's vegetation. California Indians applied fire to nearly every ecosystem type for a variety of reasons and at spatial and temporal scales appropriate to achieve a sustainable landscape. This application of fire extended to riparian ecosystems (see Hankins 2009; Lake 2007), where many resources such as basketry plants are found.

It is recognized that fire leads to an increase in heterogeneity and maintenance of species distribution as well as increased production and quality of floral resources and reduction of fuels, nuisance species, and diseased individuals (Driver 1939; Lewis 1973; Biswell 1989; Anderson 1994, 1996, 2005, 2006; Arno and Allison-Bunnell 2002). The application of various management techniques would depend on objectives. These can range from the improving the quality of an individual shrub to "cleaning up" the landscape. The implementation of fire over millennia likely led to selection for species tolerant of such processes (Martin and Sapsis 1992). Subsistence activities involving fire would maintain a mosaic of vegetation patches that synergistically complemented other processes including flooding.

Although the benefits of indigenous burning practices are widely recognized, there is often a failure to acknowledge or fully understand the rationale for what, when, and why fires are utilized (Yibarbuk et al. 2001). Naveh (1998) and De Lacy and Lawson (1997: 176) suggest that achieving biodiversity conservation and habitat restoration using fire requires an understanding of the tribal cultural context under which the systems co-evolved. By reading the landscape and using this knowledge, the spatial and temporal scale of burns could be adjusted to achieve outcomes such as fires of low-mixed intensity and severity with high spatial complexity that characterized traditional California Indian burning (see Anderson 2006; Lewis 1973). Oral stories from and observations by California Indian traditional cultural practitioners, and ethnographic and explorer records (see Driver 1939; Sutter 1939; Belcher 1843) note that the beginning of the wet season was when most riparian burning occurred as part of clean-up burning activities. The timing of burns changed as objectives changed; for example burning was undertaken in the dry season to fell trees or regenerate forage for herbivores. The goal of this study is to expand knowledge of fire effects on riparian vegetation in order to inform resource management and conservation practices. This study investigates the effects of seasonally varying prescribed fires on the riparian vegetation of central California.

\section{Methods \\ Biocultural}

Ethnographic information was gathered to document and develop an understanding of the knowledge of indigenous burning practices in riparian ecosystems in central California. This information was collected through: (1) written accounts, tribal dictionaries, and published sources; (2) informal unstructured interviews with local tribal individuals (e.g., elders and traditional cultural practitioners); and (3) informal interviews with other local land owners/managers (e.g., farmers and preserve managers with generational ties to the region).

Based upon the collected information an experimental design was developed to test the following hypotheses: (1) native plant species richness and abundance (total observations of individual species) increase as a result of burning, (2) summer and spring burning results in a decrease in shrub, vine, and canopy cover, and (3) summer and spring burning results in a greater abundance and richness of non-native ground cover vegetation.

\section{Field sampling}

Field treatments of ladder fuel removal followed by burning were conducted at the Jan T. Lowrey Cache Creek Nature Preserve (Cache Creek) located near Woodland, CA, and at the Natural Resource Conservation Service's Plant Material Center (Mokelumne River) located in Lockeford, CA (Figure 1). These areas are located in the traditional territories of the Wintun (Patwin) and Plains Miwok (Miwko), respectively. These sites were selected due to their similarities in plant taxa, vegetation architecture, plant age class composition, and the interest of site managers in implementing indigenous burning in the context of research. Both study sites support native and nonnative plants characterized as Valley Foothill Riparian vegetation (Grenfell 1988). Dominant species include willow/cottonwood (Salix spp./Populus fremontii) or willow/box elder (Salix spp./Acer negundo) canopies with an understory of grasses, herbs, and forbs including Santa Barbara sedge (Carex barbarae), creeping wild-rye (Leymus triticoides), stinging nettle (Urtica doica), and mugwort (Artemesia douglasiana). Some of the nonnative species found within the study sites include ripgut brome (Bromus diandrus) and Himalayan blackberry (Rubus discolor).

Each site occupies approximately 2.4 ha of control and treatment (fuel reduction followed by burn treatments) areas. Prior to treatment, in the spring of 2002, line 


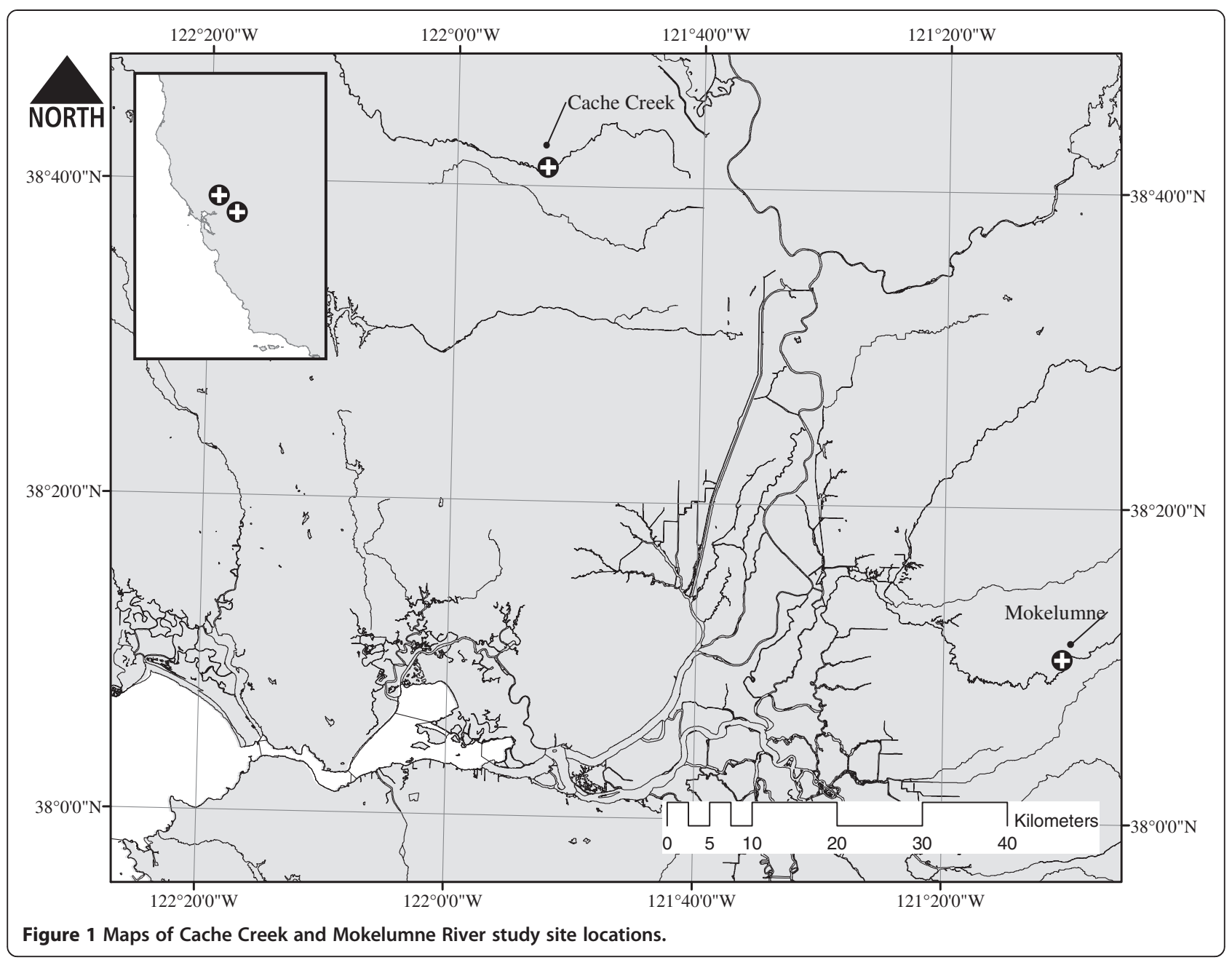

intercept transects (see Elzinga et al. [1998: 181]) $15.2 \mathrm{~m}$ in length were established at control and treatment areas perpendicular to the flow of water (transect length reflects the narrowest width of riparian vegetation); spring and summer transects were installed in patches of unburned vegetation within the areas to be burned following the early wet season burn (see Table 1). Vegetation along the line intercept transects was recorded within three vertical strata: ground, shrub/vine, and tree canopy. Transects were surveyed each spring (during the peak of flowering of ground cover species) and species presence, abundance, and cover recorded. Ground strata observations consisted of individual plants centered

Table 1 Transect replication by treatment classification at each study site

\begin{tabular}{lccccc}
\hline Siteltreatment & Control & $\begin{array}{c}\text { Fall } \\
\text { burn }\end{array}$ & $\begin{array}{c}\text { Summer } \\
\text { burn }\end{array}$ & $\begin{array}{c}\text { Spring } \\
\text { burn }\end{array}$ & Total \\
\hline Cache Creek & 4 & 4 & 0 & 4 & 12 \\
Mokelumne River & 4 & 4 & 2 & 2 & 12 \\
\hline
\end{tabular}

nadir to the line and relative to the transect endpoint furthest from water. Shrub/vine and tree canopy cover were recorded as the total area along the plane of the line transect occupied by vegetative cover divided by the total length of the line transect. Post-treatment monitoring was conducted for two growing seasons following each burn treatment. Photo points located along each transect at the end most distant from the water were used to visually assess change along these transects.

Initially, this study aimed to compare burns in fall (early wet season) and summer (dry season), which are the traditional times of burning. However, conflict with the nesting of migratory birds, air quality, and staffing problems eliminated summer treatments. Thus transects that were to be burned in summer were instead burned the following spring.

\section{Site preparation and burning}

Between late August and mid-November 2002, ladder fuels (e.g., branches and entangled vines on trees) within the treatments were removed to a height of approximately 
$1.8 \mathrm{~m}$ and burned off-site to minimize potential crown scorch and create a structure similar to what may have existed had these sites been subject to frequent traditional burning. Some vine-entangled deadfall trees and branches $(1,000+h$ fuels $)$ were removed for safety purposes, but none of these fuels were located along transects. The remaining fuels consisted mostly of fresh leaf litter, grasses, and twigs classified as 1- to 10-h fuels, and a limited amount of 100- to 10,000-h fuels. No quantitative estimates of fuel loading were made; however, conditions were similar to CDO 07 and CDO 08 described by Ottmar et al. (2004).

Fall and summer fires were implemented by burning along the edges of the intended treatment sites, then traversing the area with either drip torch and/or road flares to set spot ignitions, which were allowed to burn throughout the study burn area (see Hankins 2009 for greater detail). Fall burning commenced following the onset of the rainy season. At Cache Creek burning occurred on 20 and 27 November 2002, and at the Mokelumne River on 8 December 2002. The burns at Cache Creek were set in the early afternoon after the drying time for 1-h fuels had been met, but before afternoon relative humidity began to rise. The last rain occurred on 5 November, thus a period of drying had occurred prior to ignition. Approximately $5.72 \mathrm{~cm}$ of rain had fallen prior to the ignition dates. Air temperatures at Cache Creek burns were between 17.2 and $23.8^{\circ} \mathrm{C}$, winds below $1.6 \mathrm{~km} \mathrm{~h}^{-1}$ from the north, and relative humidity was approximately $30 \%$ at each burn. The burn at the Mokelumne River site was similarly implemented in the early afternoon. Approximately 6.3 $\mathrm{cm}$ of rain had fallen prior to ignition. The most recent precipitation in relation to the burn date occurred on 6 December but was not measurable. The air temperature at this burn was $14.4^{\circ} \mathrm{C}$, northerly winds were approximately $4 \mathrm{~km} \mathrm{~h}^{-1}$, and the relative humidity was approximately $57 \%$. With the exception of the 20 November burn, the air temperature, wind, and relative humidity were recorded on a Kestrel ${ }^{\circ} 3000$ handheld wind meter. The 20 November weather data were obtained via an onsite weather station. Precipitation data were obtained from the University of California Integrated Pest Management weather data web site (University of California Integrated Pest Management 2012). Under these weather conditions, the fires could be characterized as creeping with flame heights ranging between 0.3 and $1.8 \mathrm{~m}$ and were of low intensity and low severity. At Cache Creek, approximately one-half of the treatment area was burned, leaving a mosaic of small burned and unburned patches. At the Mokelumne River site, fuel moisture and high relative humidity limited the spread of the fire, but burning occurred in plots that at a minimum were approximately $9 \times 21 \mathrm{~m}$ in area surrounding the transects.
Summer burning occurred only at the Mokelumne River site on 2 July 2005. As described above, only two transects were treated for the summer burn treatment. These burns were implemented in the morning when relative humidity was high and wind speed low. The last rain prior to this burn occurred on 9 June 2004. The grasses present throughout most of the site were cured. During the burn, the air temperature was approximately $23.8^{\circ} \mathrm{C}$, winds varied between 1.4 and $4.5 \mathrm{~km} \mathrm{~h}^{-1}$ from the north, and relative humidity was approximately $53 \%$. Similar to the fall burns described above, the summer burns were of low intensity and low severity. Canopy shading was a key influence on the flammability of fine grasses within the summer treatment areas.

Spring burning occurred at the Cache Creek and Mokelumne River over a period of several days throughout the month of March 2005. Spring burning was implemented with a hand-held torch similar to that described by Vitelli and Madigan (2004) to burn plants that were not fully cured. Burn conditions were not recorded for these burns due to the fact that the treatment was not a conventional prescribed fire. A minimum area of $9 \times 21 \mathrm{~m}$ was burned surrounding each transect unless fuel conditions allowed greater spread.

Fire residency times and temperatures at each transect were recorded with a $\mathrm{Hobo}^{\circ}$ type $\mathrm{K}$ data logger wrapped in cotton towels and plastic bags buried at least $13 \mathrm{~cm}$ below the soil with the thermocouple probes protruding approximately $2.5 \mathrm{~cm}$ above the soil surface. Inconsistent data collection by these devices limited data availability for all fires. Recorded temperatures during fires ranged from 42.5 to $454^{\circ} \mathrm{C}$, the former temperatures recorded at stands of grasses and blackberries burned by the propane torch, the latter being for fine woody fuels ignited during a fall broadcast burning. For each event the heating lasted for approximately $5 \mathrm{~min}$. The temperature for a grass-dominated area during a fall burn reached a high of $107^{\circ} \mathrm{C}$ for approximately $1.5 \mathrm{~s}$.

\section{Data analysis}

The effects of treatment on species abundance, richness, richness of native species, proportion native species abundance (calculated as the total number of native species observations divided by the total number of all species observed by transect), proportion native richness (calculated as the native species richness divided by the total richness by transect), shrub/vine cover, and canopy cover were analyzed across parameters including transect, site, treatment type, and year. Statistical analyses was performed in JMP 7.0.2 @ (SAS Institute, Inc., Cary, NC). Given the unbalanced study design, a standard least squares fit model with an emphasis on effects leveraging, and the restricted maximum likelihood (REML) method were selected to model the effects of 'site' as a 
random parameter and 'year' and 'treatment' as fixed parameters on vegetation response. Additional parameters included 'annual precipitation' for the year and 'time from treatment,' but these parameters were found not to be significant and were removed from further analysis. A variability chart was developed to compare the effects of aggregated treatment type by year. Data were also aggregated by treatment type and site to evaluate Shannon Evenness of habitat similarity between years and treatments. This measure suggests the amount of uncertainty of not finding all of the species in common between samples of a given set of transects, whereby the more species represented, the larger the indices value (Krebs 1989).

\section{Results}

A total of 52 plant species were identified at the line transects of which 49 belonged to the ground strata. Species frequently observed included ripgut brome (Bromus diandrus), creeping wild rye (Leymus triticoides), bur chervil (Anthriscus caucalis), Mexican spangletop (Leptochloa uninervia), Santa Barbara sedge (Carex barbarae), soft chess brome (Bromus hordeaceus), mugwort (Artemesia douglasiana), California blackberry (Rubus ursinus), Himalayan blackberry (Rubus discolor), sandbar willow (Salix exigua), red willow (Salix laevigata), and box elder (Acer negundo). Non-native species represented more than half of the richness (27 species).

The fixed effects of treatment were significant across all parameters excluding 'canopy' cover as follows: 'richness' $\left(F_{3,82.46}=2.87, p=0.0414\right)$; 'richness of native plants' $\left(\mathrm{F}_{3,82.45}=4.5, p=0.0057\right)$; 'proportion native plant abundance' $\left(\mathrm{F}_{3,82.27}=7.14, p=0.0004\right)$; 'proportion native richness' $\left(\mathrm{F}_{3,82.3}=7.14, p=0.0003\right)$; shrub/vine cover $\left(\mathrm{F}_{3,82.5}=\right.$ $3.07, p=0.0325)$; and 'canopy cover' $\left(\mathrm{F}_{3,1}=0.68, p=\right.$ $0.6890)$. However, 'year' was found to be an insignificant parameter, while 'shrub/vine cover' was the most significant $\left(\mathrm{F}_{1,82}=1.24, p=0.26820\right)$ and proportion native plant abundance' the least $\left(\mathrm{F}_{1,82}=0.16, p=0.6908\right)$. The REML variance component estimates for the model suggest that the parameter site contributes a range of variability between -2.33 and $27.1 \%$ for the parameters described; the former for canopy cover, the latter for the proportion native species.

The least squares means provide an indication of the effects of treatment for the parameters described (see Table 2). While individual transects may have exhibited greater variability over the course of this study, these means capture the larger trends by treatment type.

Variability charts enable the analysis of observation variability across the measured parameters. For 'richness,' the fall burn group means increase slightly following treatment, whereas the spring and summer treatments show a slight decrease. By comparison, the control group means are relatively even. 'Native species richness' is generally
Table 2 Least squares means ( \pm standard error) for parameters by treatment type

\begin{tabular}{lcccc}
\hline $\begin{array}{l}\text { Response } \\
\text { parameter }\end{array}$ & Control & $\begin{array}{c}\text { Fall } \\
\text { burn }\end{array}$ & $\begin{array}{c}\text { Spring } \\
\text { burn }\end{array}$ & $\begin{array}{c}\text { Summer } \\
\text { burn }\end{array}$ \\
\hline $\begin{array}{l}\text { Species richness } \\
\text { Native species }\end{array}$ & $4.68 \pm 0.8$ & $5.24 \pm 0.9$ & $3.82 \pm 0.9$ & $7.25 \pm 1.3$ \\
richness & $2.58 \pm 0.5$ & $2.63 \pm 0.6$ & $2.27 \pm 0.6$ & $3.7 \pm 0.8$ \\
$\begin{array}{l}\text { Proportion native } \\
\text { species }\end{array}$ & $22.9 \pm 0.1$ & $53.4 \pm 0.2$ & $52.7 \pm 0.2$ & $31.6 \pm 0.2$ \\
$\begin{array}{l}\text { Proportion native } \\
\text { species richness }\end{array}$ & $28.2 \pm 0.1$ & $54.8 \pm 0.1$ & $57.9 \pm 0.1$ & $52.7 \pm 0.2$ \\
$\begin{array}{l}\text { Percent shrub/vine } \\
\text { cover }\end{array}$ & $34.3 \pm 8.5$ & $19.0 \pm 9.6$ & $21.5 \pm 10.2$ & $3.4 \pm 14.3$ \\
$\begin{array}{l}\text { Percent canopy } \\
\text { cover }\end{array}$ & $59.5 \pm 3.9$ & $63.6 \pm 6.5$ & $71.3 \pm 6.5$ & $71.6 \pm 6.6$ \\
\hline
\end{tabular}

highest amongst the fall and spring burn treatments as noted by the observed group means, but it decreased amongst summer burns. The 'proportion native' group means are generally highest amongst all burn treatments, but the post-treatment responses contrast: for fall burns there is an overall decrease from pre-treatment means, spring burn means increase post-burn, and summer burns exhibit an initial decrease post-burn then increase in yeartwo post-burn. The 'proportion native richness' group means are also highest amongst the burn treatments. Here the post-burn means continue to increase post-burn, but the summer burn means initially decrease immediately following the burn. 'Shrub/vine cover' means are generally lowest amongst all burn treatments, with a noticeable decline following treatment, but spring burn means are most similar to the control group means. 'Canopy cover' means exhibit little change following treatment.

The Shannon Evenness indices indicate that evenness differs by treatment type and time (see Figure 2). The overall evenness exhibits an initial decrease in evenness post-treatment for fall burning and an overall increase in evenness post-treatment for spring and summer burning. The general trend for native evenness increases following all burn treatments, with the greatest increase following the spring burn at the Mokelumne River.

Photo monitoring indicates a rapid rate of recovery following burn treatments (Figure 3). Figure 3 represents the rate of vegetation recovery at one fixed photo point over a 1 -year period. Similar rates of recovery were observed at the other photo points.

\section{Discussion}

The results show that treatment groups differed significantly from each other across time despite similarities in the aggregated composition of plant species. While the least squares model did not show significant inter-annual variation within treatment groups, the variability chart and Shannon evenness illustrate that shifts in species 


\section{Evenness}

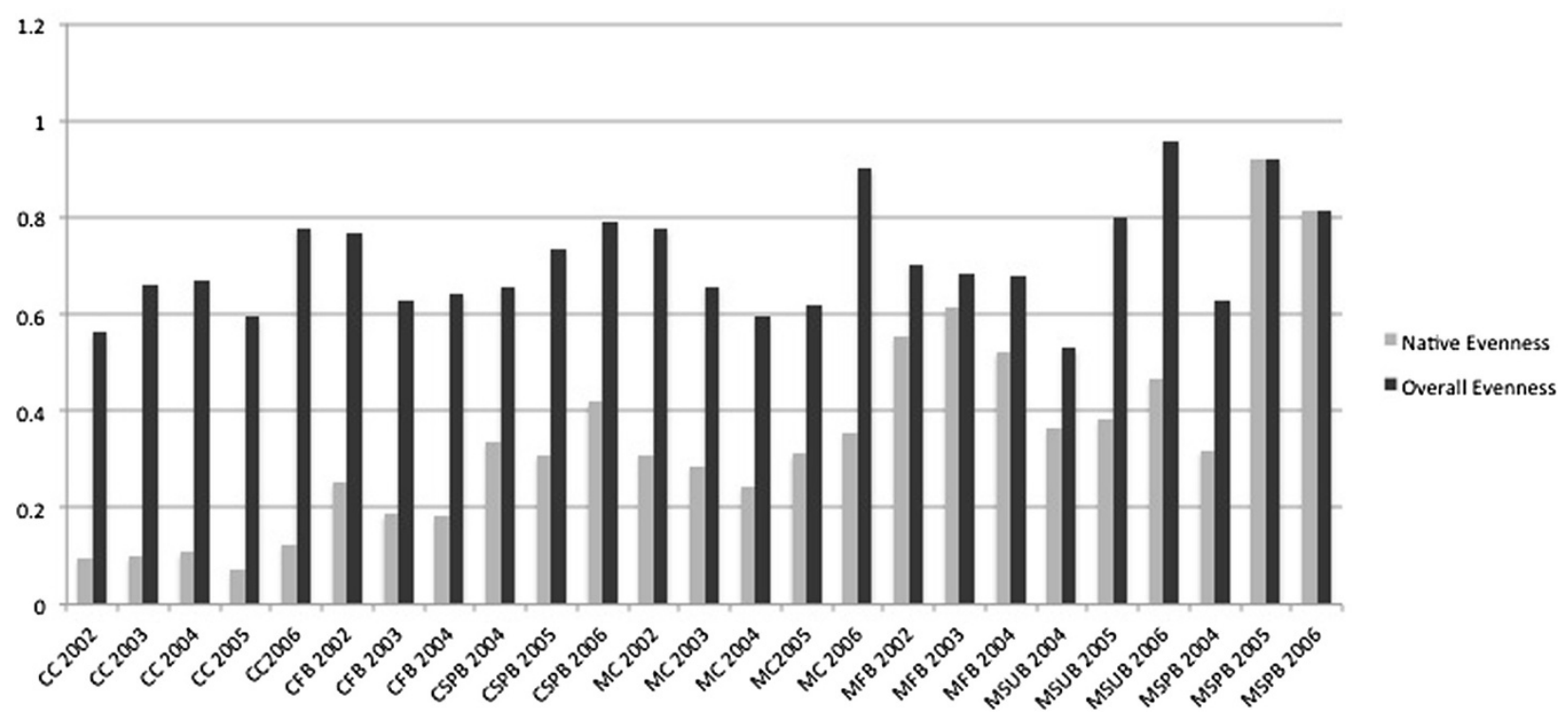

Figure 2 Shannon Evenness based on the aggregated transect data for each study site by treatment and year fitted with a trend line. Higher values indicate higher plant diversity within each treatment. The treatment abbreviations are as follows: those beginning with $\mathrm{C}$ are Cache Creek, and $\mathrm{M}$ are Mokelumne River; followed by the treatment codes of $\mathrm{C}=$ control, $\mathrm{FB}=$ fall burn, $\mathrm{SPB}=$ spring burn, and SUB $=$ summer burn; and calendar year (2002-2005).
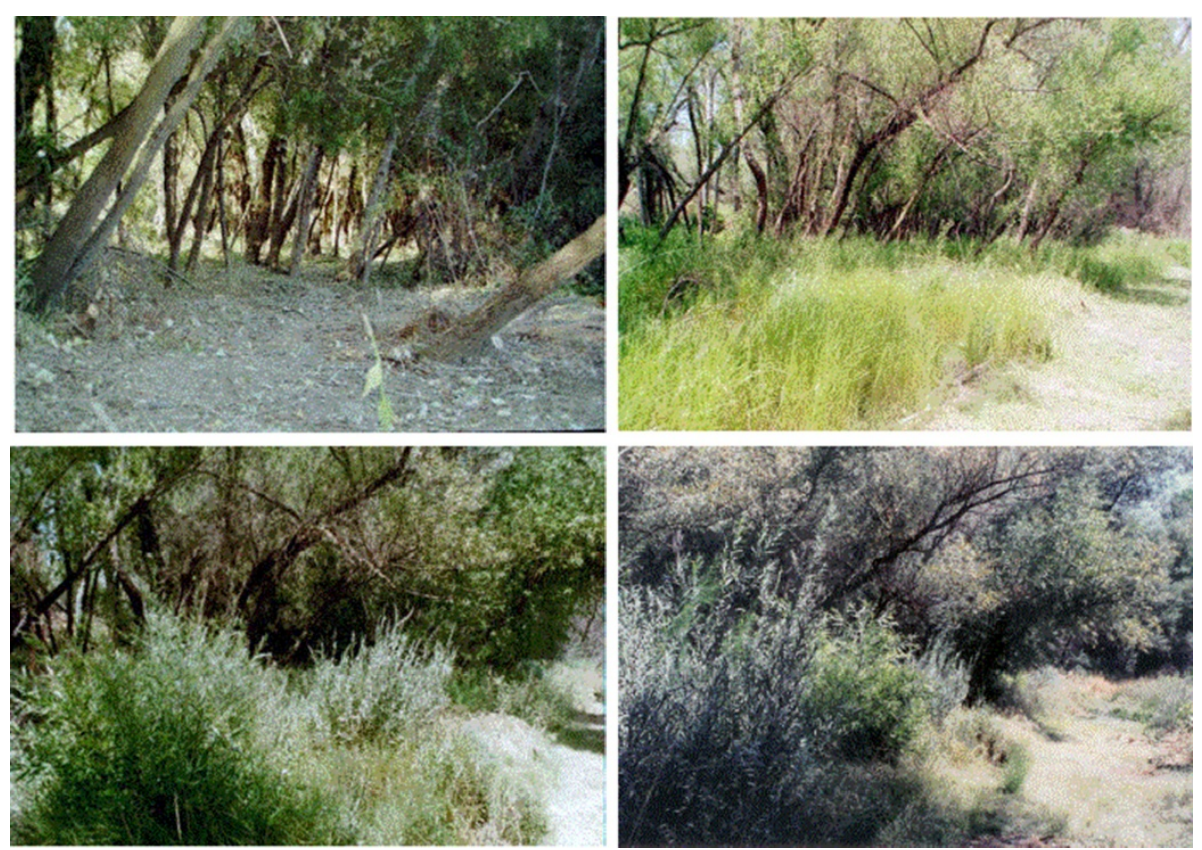

Figure 3 One-year sequential response to fall burn treatment at the Cache Creek photo point. Upper left depicts pre-burn fuel reduction Upper right depicts the spring growth of primarily native grasses following the fall burn treatment. Lower left depicts the rapid growth of willows in early summer. Lower right depicts the recovery of woody structure at the end of one growing season. 
composition by aggregated treatment group did occur across the timespan of this study. Here, the measures of richness, abundance based on total counts of individual species, and cover have been used to demonstrate resiliency by treatment type. While overall richness did not change dramatically across treatments in time, it is apparent that fire contributes to maintaining richness within this system, thus supporting prior assertions by Martin and Sapsis (1992). Furthermore, the abundance of those species observed throughout this study suggests that native species may be most resilient to fire. Given that more than half of the diversity on these sites is attributed to non-native species, and pre-treatment data noted the prevalence of these species, it is encouraging to see the maintenance or increase in native species richness and an increase in the proportion of native species amongst all burn treatments. The results support the hypothesis that native plant diversity increases while the proportional abundance of native species decreases as a result of fall burning, which is converse to Bêche et al. (2005). Additionally, the results suggest that spring and summer burning do not contribute to a disproportionate shift in overall richness or total number of individuals compared to the proportion native. Hence, spring and summer burns do not necessarily lead to an increase in non-native species richness or abundance.

With respect to shrub and vine cover, the data suggest that all burn treatments have lower percent cover relative to the controls. However, spring burning appears to benefit shrubs and vine cover more than fall or summer burning. The data suggest that none of the burn treatments resulted in a decrease in tree canopy cover. In comparing the various treatments, spring and summer burn treatments had higher percent canopy cover, but that is likely a product of existing conditions along the transects and not from specific treatments. Thus, the hypothesis that summer and spring burning results in a decrease in canopy cover by woody vegetation is rejected.

It was predicted that burning during the active growing season would make trees susceptible to top-kill considering their general lack of thick bark as insulation from fire; but given the low intensity of these fires no crown mortality was observed. Within the broader area treated by the summer burn some basal sprouting was noted on trees with scorched trunks; this was not observed in relationship to other burn treatments. For some species, such as willows and oaks, this basal sprouting would be culturally desirable to generate shoots for basketry (see Anderson 2005).

The recovery of woody plant structure can be quite rapid, and within a year or two woody plants can become impenetrable thickets (see Figure 3). Although cover by small trees, shrubs, and vines may be temporarily reduced, this cover quickly recovers from any adverse effects of burning. However, repeated burning could result in a decrease in cover of woody species similar to the findings of Quinlan et al. (2003).

The observed decrease in overall evenness for fall burns increases for spring and summer burning. This result contrasts with previous findings which suggest that burning promotes an increase in biodiversity (Lewis 1973; Biswell 1989; Martin and Sapsis 1992; Anderson 1994, 2005; Arno and Allison-Bunnell 2002). With the exception of the Mokelumne River fall burns, closer examination of the native species evenness yields a similar outcome. A variety of factors may explain the observed changes to the evenness indices values, including the timing of the burns.

The observed variation in evenness indices is likely a product of the synergistic effects of treatment; specifically, where the proportional native species richness is high, there is generally a reduction in non-native richness (see Figure 2). Additionally, the resiliency of certain taxa, such as those that recover rapidly from fire (e.g., perennial grasses and vines) may lead to a competitive advantage over taxa that recover slowly. Many riparian species are successful at rapid colonization of disturbed areas, such as burned areas, due to their seed dispersal mechanisms (Dwire and Kauffman 2003). Vegetative propagation can also aid in colonizing recently burned areas. The life history and phenology of the affected species in relation to the timing and severity of the burn are important factors that should be considered with respect to achieving desired outcomes. For instance, native perennial grasses (e.g., Santa Barbara sedge, creeping wild rye) were most abundant following fall burns at Cache Creek. Fall burns coincided with the germination of primarily non-native grasses, herbs, and forbs in the earliest part of the wet season, which enabled the natives to germinate and grow without competition from the introduced taxa. Repeated burning under this scenario could ultimately deplete the seedbank of nonnative grasses, herbs, and forbs, and yield to native grass, herb, and forb dominance.

Where native vegetation exists, fall and spring burning increases native species richness, while the abundance of individual native species generally increases following spring and summer burning. However, a limited number of summer burn treatments means this observation should be used with caution. As Keeley (2001) states, the spread and/or control of non-native taxa with fire is of general interest to conservationists and land managers, but this area of study is not well researched. In fact, non-native species present a major challenge in restoring indigenous fire regimes to riparian ecosystems (see Pfeiffer and Voeks 2008; Pfeiffer and Ortiz 2007). If the goal is to restore native plant dominance within an ecosystem with fire, then perhaps the short-term remedy may involve burning at times that are not typical for indigenous fires. 
Although 'time from fire' was an insignificant parameter during the testing of models, there was either maintenance of or an overall decrease in native species richness as time from treatment increased. Similarly, the 'proportion native' decreased following fall burn treatment, increased following treatment for spring burns, and declined before rebounding for summer burns. Overall, the 'proportion native richness' increased amongst all burn treatments. This suggests that relatively frequent fire return intervals may play an important role in establishing and maintaining native species richness and abundance of native species, and should be considered in future studies.

\section{Conclusions}

This research has demonstrated the efficacy of indigenous and alternative burn treatments as a means to manage and maintain heterogeneity amongst species and habitats. Given the rarity of riparian ecosystems in California's Central Valley and other regions, the seasonal application of prescribed fire can be effective in achieving conservation objectives while also maintaining cultural obligations of indigenous communities. Fall and summer burn treatments in particular produced many outcomes known from traditional knowledge (e.g., enhancement of native species and improved growth of basketry plants as described by Pfeiffer and Ortiz [2007]). While these outcomes were not specifically quantified in cultural terms they are still of significance to cultural practitioners seeking to improve resources. Much remains to be studied regarding indigenous fires in riparian ecosystems. Future studies should consider variations in spatial extent of burning, repeated burn treatments (including mixed seasonal burn treatments such as combined fall and summer burning), and burn prescriptions of mixed intensity and severity.

\section{Competing interests}

The author declares that he has no competing interests.

\section{Author's information}

DLH is currently an Associate Professor in the Department of Geography and Planning at California State University, Chico and Field Director for the California State University, Chico Ecological Reserves. DLH is engaged in furthering the application and research of indigenous stewardship to achieve conservation, restoration, and management objectives.

\section{Acknowledgements}

This research would not have been possible without the support and participation of traditional cultural practitioners (comprised of members representing various tribal groups including Maidu, Wintun, and Plains and Northern Sierra Miwok) and others including my family, Shannon Brawley, Michael McGirr, Jacquelyn Ross, Kathy Wallace, Kimberley and Curt Stevenot, Molly Ferrell, Diana Almendariz, Harry and Lee McQuillen, the Willow-Oak Fire Department, and Mokelumne Fire Department and the staff at the NRCS Lockeford Plant Materials Center. Drs. Deborah Elliott-Fisk, Michael Barbour, and Melissa Nelson provided useful guidance on the development of this project. Comments provided by anonymous reviewers on an earlier draft have helped to refine this manuscript. Drs. Kathy Gray and Nancy Carter provided useful discussions about statistical models for analysis of unbalanced design. I am grateful to the late Jan T. Lowrey for inviting this research opportunity and enabling the return of indigenous fires to the riparian forest. Partial funding for this research was obtained through the Community Forestry and Environmental Research Program.
Received: 8 February 2013 Accepted: 9 July 2013

Published: 29 July 2013

\section{References}

Agee JK (1999) A coarse-filter strategy. Forum Appl Res Publ Pol 14(1):15-19 Anderson K (1993) Native Californians as Ancient and Contemporary Cultivators. In: Blackburn TC, Anderson K (eds) Before the Wilderness: Environmental Management by Native Californians. Balena Press, Menlo Park, CA, pp 151-174

Anderson MK (1994) Prehistoric anthropogenic wildland burning by huntergatherer societies in the temperate regions: a net source, sink, or neutral to the global carbon budget. Chemosphere 29(5):913-934

Anderson MK (1996) The ethnobotany of deergrass, Muhlenbergia rigens (Poaceae); it's uses and fire management by California Indian tribes. Econ Bot 50(4):409-422

Anderson MK (2005) Tending the wild: Native American knowledge and the management of California's natural resources. University of California Press, London

Anderson MK (2006) The use of fire by Native Americans in California. In: Sugihara NG, van Wagtendonk JW, Shaffer KE, Fites-Kaufman J, Thode AE (eds) Fire in California's ecosystems. University of California Press, Berkeley

Arno SF, Allison-Bunnell S (2002) Flames in our forests: disaster or renewal? Island Press, Washington D.C

Bêche LA, Stevens SL (2005) Resh VH (2005) Effects of prescribed fire on a Sierra Nevada (California, USA) stream and its riparian zone. Forest Ecol Manage 218:37-59

Belcher $E$ (1843) Narrative of a voyage around the world, performed in H.M.S "Sulpher", during the years 18361842,- vol. 2. Henry Colburn, London

Bendix J, Cowell CM (2010) Impacts of wildfire on the composition and structure of riparian forests in southern California. Ecosystems 13(2010):99-107

Beschta RL, Rhodes JJ, Kauffman JB, Gresswell RE, Minshall GW, Karr JR, Perry DA, Hauer FR, Frissell CA (2004) Postfire management on forested public lands of the western United States. Conserv Biol 18:957-967

Bisson PA, Rieman BE, Luce C, Hessburg PF, Lee DC, Kershner JL, Reeves GH, Gresswell RE (2003) Fire and aquatic ecosystems of the Western USA: current knowledge and key questions. Forest Ecol Manage 178:213-229

Biswell H (1989) Prescribed burning: In California wildlands vegetation management. University of California Press, Berkeley

Busch DE (1995) Effects of fire on southwestern riparian plant community structure. Southwest Nat 40(3):259-267

De Lacy T, Lawson B (1997) The Uluru/Kakadu model: joint management of aboriginal-owned national parks in Australia. In: Stevens S (ed) Conservation through cultural survival: indigenous peoples and protected areas. Island Press, Washington, D.C.

Driver HE (1939) Culture element distributions: X. Northwest California. UC Anthropol Rec 1(6):297-435

Dwire KA, Kauffman JB (2003) Fire and riparian ecosystems in landscapes of the Western USA. Forest Ecol Manage 178:61-74

Ellis LM (2001) Short-term response of woody plants to fire in a Rio Grande riparian forest, central New Mexico, USA. Biol Conserv 97:159-170

Elzinga CL, Salzer DW, Willoughby JW (1998) Measuring and monitoring plant populations. U.S. Department of Interior, Bureau of Land Management, Denver

Everett R, Schellhass R, Ohlson P, Spurbeck D, Keenum D (2003) Continuity in fire disturbance between riparian and adjacent sideslope Douglas-fir forests. Forest Ecol Manage 175:31-47

Faber PM, Holland RF (1996) Common riparian plants of California: a field guide for the layman. Pickleweed Press, Mill Valley, CA

Fulé PZ, Cocke AE, Heinlein TA, Covington WW (2004) Effects of an intense prescribed fire: is it ecological restoration? Restor Ecol 12(2):220-230

Gom LA, Rood SB (1999) Fire induces clonal sprouting of riparian cottonwoods. Can J Bot 77:1604-1616

Grenfell WE (1988) Valley foothill riparian. In: Mayer KE, Laudenslayer WF (eds) A guide to wildlife habitats of California. California Department of Forestry and Fire Protection, Sacramento

Haflofsky JE (2009) Hibbs DE (2009) Controls on early post-fire woody plant colonization in riparian areas. Forest Ecol Manage 258:1350-1358

Hankins DL (2009) The effects of indigenous prescribed fire on herpetofauna and small mammals in two Central Valley California riparian ecosystems. CA Geograph 49(2009):31-50

Keeley JE (2001) Fire and invasive species in Mediterranean-climate ecosystems in California. In: Galley KEM, Wilson TP (eds) Proceedings of the invasive species 
workshop: the role of fire in the control and spread of invasive species. Fire conference 2000: the first national congress on fire ecology, prevention, and management. Miscellaneous publications no. 11. Tall Timbers Research Station, Tallahassee, FL

Kobziar LN (2006) McBride JR (2006) Wildfire burn patterns and riparian vegetation response along two northern Sierra Nevada streams. Forest Ecol Manage 222:254-265

Krebs CJ (1989) Ecological methodology. Harper and Row, New York

Lake FK (2007) Traditional ecological knowledge to develop and maintain fire regimes in northwestern California. Management and restoration of culturally significant habitats. Oregon State University, Klamath-Siskiyou Bioregion, PhD Dissertation

Lewis HT (1973) Patterns of Indian burning in California: ecology and ethnohistory. In: Blackburn TC, Anderson K (eds) Before the wilderness: environmental management by native Californians. Balena Press, Menlo Park, CA pp, pp 55-116

Martin RE, Sapsis DB (1992) Fires as agents of biodiversity: pyrodiversity promotes biodiversity. In: Harris RR, Erman DE, Kerner HM (eds) Proceedings of the Symposium on Biodiversity of Northwestern California. Wildland Resources Center Report No. 29. University of California, Berkeley, pp 150-157

Naveh Z (1998) Ecological and cultural landscape restoration and the cultural evolution towards a post-industrial symbiosis between human society and nature. Restor Ecol 6(2):135-143

Ottmar RD, Vihnanek RE, Wright CS, Olson DL (2004) Stereo photo series for quantifying natural fuels. Volume VII: Oregon white oak, California deciduous oak, and mixed-conifer with shrub types in the western United States. PMS 839. National Wildfire Coordinating Group, National Interagency Fire Center, Boise, ID

Petit NE, Naiman RJ (2007) Fire in the riparian zone: characteristics and ecological consequences. Ecosystems 10(2007):673-687

Pfeiffer JM, Ortiz EH (2007) Invasive plants impact California native plants used in traditional basketry. Fremontia 35(1):7-13

Pfeiffer JM, Voeks RA (2008) Biological invasions and biocultural diversity: linking ecological and cultural systems. Environ Conserv 35(4):281-293

Pilliod DS, Bury RB, Hyde EJ, Pearl CA, Corn PS (2003) Fire and amphibians in North America. Forest Ecol Manage 178:163-181

Quinlan A, Dale MRT, Cormack Gates C (2003) Effects of prescribed burning on herbaceous and woody vegetation in northern lowland meadows. Restor Ecol 11(3):343-350

Russell WH (2001) McBride JR (2001) The relative importance of fire and watercourse proximity in determining stand composition in mixed conifer riparian forests. Forest Ecol Manage 150:259-265

Sutter JA (1939) New Helvetia diary: a record of the events kept by John A. Sutter and his clerks at New Helvetia, California, from September 1845, to May 25, 1848. Grabhorn Press, San Francisco

University of California Integrated Pest Management (2012) University of California Integrated Pest Management. http://www.ipm.ucdavis.edu/ WEATHER/index.html

van Wagtendonk JW, Cayan DR (2008) Temporal and spatial distribution of lightning strikes in California in relation to large-scale weather patterns. Fire Ecol 4(1):34-56

Vitelli JS, Madigan BA (2004) Evaluation of a hand-held burner for the control of woody weeds by flaming. Aust J Exp Agric 44:75-81

Wills R (2006) Central Valley bioregion. In: Sugihara NG, van Wagtendonk JW, Shaffer KE, Fites-Kaufman J, Thode AE (eds) In: Fire in California's ecosystems. University of California Press, Berkeley, CA, pp 295-321

Yibarbuk D, Whitehead PJ, Russell-Smith J, Jackson D, Godjuwa C, Fisher A, Cooke P, Choquenot D, Bowman DMJS (2001) Fire ecology and aboriginal land management in Central Arnhem Land. Northern Australia: a tradition of ecosystem management. J Biogeogr 28:325-343

doi:10.1186/2192-1709-2-24

Cite this article as: Hankins: The effects of indigenous prescribed fire on riparian vegetation in central California. Ecological Processes 2013 2:24.

\section{Submit your manuscript to a SpringerOpen ${ }^{\odot}$ journal and benefit from:}

- Convenient online submission

Rigorous peer review

- Immediate publication on acceptance

- Open access: articles freely available online

- High visibility within the field

- Retaining the copyright to your article

Submit your next manuscript at $\gg$ springeropen.com 